\title{
Vision 2030 and reducing the stigma of vocational and technical training among Saudi Arabian students
}

\author{
Abdulaziz Salem Aldossari
}

*Correspondence:
aldossa6@gmail.com
Educational Policies
Department, College
of Education-King Saud
University, P.O Box 2458,
Riyadh 11451, Saudi Arabia

*Correspondence: aldossa6@gmail.com Department, College of Education-King Saud Riyadh 11451, Saudi Arabia

\begin{abstract}
Technical and vocational education and training (TVET) plays a critical role in developing essential labor market skills. In Saudi Arabia, participation in TVET has traditionally been stigmatized in favor of white-collar jobs. However, the importance of skilled labor has increased in Saudi Arabia's private sector as the country's Vision 2030 focuses on moving the economy from oil to investment. This quantitative study investigates the role of recent socio-economic transformations in changing attitudes toward TVET. Statistical analysis of a questionnaire distributed to 1007 TVET students identified a significant relationship between perceptions of TVET and gender, family income, and parental educational level.
\end{abstract}

Keywords: Technical and vocational education, Technical colleges, Training, Private sector, General education

\section{Introduction}

Saudi Arabia spends more money on education and training than any other country in the Middle East (Yamada 2018), including providing free public school, college, and university education. However, despite universal primary education and a large proportion of young people benefiting from secondary and higher education, many graduates lack the necessary qualifications for the job market (Aldossari and Bourne 2016; Bosbait and Wilson 2005; Yamada 2018). Ramady (2010: 400) pointed out that "there is a growing imbalance between the quality and quantity of occupational expertise produced by the educational system and the occupational structure demanded by the economy." The health sector accounted for $16.6 \%$ of the 591 academic programs in Saudi public universities, followed by business and management (11\%) and humanities (10.3\%; Ministry of Education 2018). Such a situation leads to poor skill matching for students who lack a sound theoretical grounding in certain professional fields (Bosbait and Wilson 2005). By limiting the role of technical and vocational training, the educational system in Saudi Arabia has failed to prepare its students for the global economy.

Due to a rise in oil revenues, from 1969 to 1980 Saudi Arabia enjoyed an economic boom that had a significant impact on engendering negative attitudes toward technical

(c) The Author(s) 2020. This article is licensed under a Creative Commons Attribution 4.0 International License, which permits use, sharing adaptation, distribution and reproduction in any medium or format, as long as you give appropriate credit to the original author(s) and the source, provide a link to the Creative Commons licence, and indicate if changes were made. The images or other third party material in this article are included in the article's Creative Commons licence, unless indicated otherwise in a credit line to the material. If material is not included in the article's Creative Commons licence and your intended use is not permitted by statutory regulation or exceeds the permitted use, you will need to obtain permission directly from the copyright holder. To view a copy of this licence, visit http://creativeco mmons.org/licenses/by/4.0/ 
and vocational training. During that period, most students chose to pursue university education rather than technical and vocational training, disdaining such employment in favor of corporate or public sector careers (Yamada 2018). Economic growth, which rose from an annual rate of 3\% in 1960 to peak at 6.37\% in 1982 (World Bank 2019), was accompanied by a population boom and corresponding increases in the working age population. During this period, the country had a shortage of engineers, manufacturers, technicians, operators, and other skilled laborers. As a result, the kingdom recruited foreign skilled nationals to fill the employment gap. Outsourcing and international hiring reduced the willingness of most Saudis to work in jobs that required substantial investments of time and effort (Mellahi and Wood 2001). The weak relationship between schools and the private sector has also led to increased demand for the recruitment of foreign skilled nationals over Saudis (Yamada 2018). In the mid-1990s, more than 65\% of public sector workers were Saudis, whereas the percentage of foreign workers in the private sector was much higher (Mellahi 2000). Official data for the first quarter of 2019 showed that workers in the private sector accounted for 67.9\% (22.3\% Saudis and $77.7 \%$ non-Saudis) of the total workforce, followed by Saudi and foreign domestic workers $(22.4 \%)$, whereas the proportion of employees in the public sector was $9.6 \%, 96 \%$ of whom were Saudis (General Authority of Statistics 2019a).

However, the recent decrease in oil demand has had a negative impact on the country's economy, resulting in a growing unemployment rate in the face of an ever-increasing population (Arabi 2018), which totaled 33,413,660 in 2018, 38\% of whom were nonSaudis (General Authority of Statistics 2019b). The government has initiated significant economic and financial reforms to end its dependency on oil and turn to the utilization of investment sources, thus emphasizing the role of the private sector and technical and vocational training (TVET) (Khashan 2017). To reduce the citizen unemployment rate, the government launched the Saudization program in 1985, which has progressively intensified requirements for the private sector to employ a certain percentage of Saudi nationals (Hussain 2020). In December 2017, the Ministry of Labor and Social Development published a ministerial resolution to incrementally increase work permit fees for foreign employees and their dependents over the following 3 years. The cost of visa renewal for expatriate workers quintupled over the period from 1994 to 2019, and the cost of hiring expatriates was increased with the introduction of compulsory health care insurance (Hussain 2020). As a result, since 2017, more than 667,000 non-Saudi workers have left the country, creating a substantial professional employment gap in the private sector (Al Omran 2018).

The success of these initiatives remains limited, as foreign workers continued to occupy just over $75 \%$ of the private sector workforce as of the first quarter of 2019 (General Authority of Statistics 2019b). A major factor limiting the ability to develop a citizen-staffed private sector workforce is the stigmatization of technical and vocational careers in the society. A cultural preference for general and higher education continues to dominate certain parts of Saudi society, leading to an imbalance between supply and demand in the labor market (Yamada 2018). As Ramady (2010: 395) noted, the Saudi Arabian educational system tends to confer "high social prestige to university education, while underestimating the significance of technological and vocational education." As a result, job creation has become a serious problem; unemployment was at a record level 
of $12.5 \%$ for the first quarter of 2019 (General Authority of Statistics 2019a). The highest category of job seekers were those with bachelor's degrees (45.8\%), while the proportion of unemployed with professional diplomas (third-level college) was dramatically lower (7.4\%).

To address such disparities, Saudi Arabia officially unveiled its ambitious economic plan, Vision 2030, in April 2016. Among the various core goals of the plan are increasing the country's economic sustainability through a reduction in oil dependency by 2030, establishing strategic inter-regional partnerships, and boosting productivity and domestic job opportunities (Faudot 2019). Vision 2030 includes solutions to key problems concerning human, social, economic, and environmental development to meet the demand of future generations (Alshuwaikhat and Mohammed 2017). As part of Vision 2030, the Saudi Arabian government has established a National Labor Gateway (TAQAT) program to expand entrepreneurial and vocational training programs to better exploit the growth opportunities offered by the young population (Saudi Vision 2030 n.d.).

However, as indicated by ongoing employment trends, the success of the Saudi government's educational initiatives depends on the development of positive attitudes toward TVET. The major cultural and social issues in Saudi Arabia that negatively affect the TVET system concern gendered restrictions and the perceptions of most Saudis that skill-based and manual qualifications lead to less prestigious careers (Mellahi 2000). The opening of broader job and career opportunities through Vision 2030 initiatives aims to stimulate a significant shift in youth and female participation in vocational and technical education and in related occupations (Alshuwaikhat and Mohammed 2017). To evaluate the success of the government's socio-economic initiatives in changing perceptions toward TVET, this study applied capability theory to quantitatively assess the perceived impact of the economic and social transformations embodied in Vision 2030 among Saudi vocational students. More specifically, the study was structured around the following research questions:

- Are vocational students' attitudes concerning the economic transformation's impact on the acceptability and viability of TVET significantly affected by the respondents' gender, marital status, study program, family income, and parents' level of educational attainment?

- Are vocational students' attitudes concerning the social transformation's impact on the acceptability and viability of TVET significantly affected by the respondents' gender, marital status, study program, family income, and parents' level of educational attainment?

\section{Theoretical framework}

This study followed Powell and McGrath's study (2014) and applied a capability approach to examine the problem. Developed by Amartya Sen (1993) and considerably further discussed by Martha Nussbaum (2007), among others, this approach advocates the importance of enhancing people's freedoms and genuine opportunities to attain wellbeing (Dang 2014). The main elements of the capability approach are capability, functioning, freedom, and conversion factors. Capability (opportunity) is defined as what a 
person is able to do or able to be, and functioning is related to achievement (Sen 2005: 153), whereas freedom is recognized as "acting freely" and "being able to choose," which are "directly conducive to "well-being"' (Sen 1992: 50). Conversion factors describe variability functioning and capability resources (Sen 1992, 1999, 2009), and are categorized into personal, social, and environmental factors. Personal factors encompass variables such as gender, age, and health, whereas institutions and sociocultural norms are considered social conversion factors, and environmental factors include aspects of the physical surroundings such as climate, the built environment, and infrastructure (Dang 2014). The implications of the capability approach in the literature are broad; it can be used as a framework to assess people and social environments, design and evaluate policies, or suggest social modifications (Robeyns 2006).

The capability approach has been mentioned extensively in the TVET literature (Powell and McGrath 2014; Lambert and Vero 2013; McGrath 2012). McGrath (2012) argued that the capability approach provides "a wider and more person-centred theory and practice of learnings-for-lives" (p. 15). Lambert and Vero (2013) assessed the impact of firms' vocational training policies and employees' capability to aspire for learning. They found that the main determinant of the capability to aspire is related to environmental factors that include training policy, and they highlighted the importance of capability of voice which is identified as the ability to express views and concerns. Powell and McGrath (2014) discussed the use of the capability approach and its potential contribution to TVET evaluation in South Africa and highlighted its value for advancing social justice, human rights, and poverty alleviation by prioritizing the needs of people over the economy.

In the context of Saudi Arabia, the government seeks to provide resources that support vocational education; however, attitudes toward TVET have been negative due to the economic boom, which has resulted in an industrial and technical sector workforce that is predominantly composed of foreign workers. As a result, Vision 2030 policies explicitly aim to change the socio-economic factors stigmatizing TVET in the country (Khashan 2017). Belcher and DeForge (2012) defined stigma as a negative attitude and perception indicating social disapproval and rejection, which influences a person's feelings of being guilty, shamed, and inferior, as Falk (2010) asserts. Specifically, Gullekson (1992) defined families' perspective toward stigma as encompassing fear, loss, lowered family esteem, shame, secrecy, distrust, anger, inability to cope, hopelessness, and helplessness. Markowitz (1998) emphasized that stigmatizing attitudes can cripple psychological wellbeing and promote disability by impeding social integration, the performance of social roles, and quality of life. Hence, the freedom concept can be promoted to encourage individuals to choose among different ways of living and different ways of 'being and doing' without fearing stigma (Sen 1992). From the capability perspective, the process of converting available resources into well-being is dependent on the individual, social, and environmental factors that influence the ability to convert resources into functionings (outcomes or achievements) and capabilities (real opportunities).

This study examined both personal factors (gender, marital status, monthly family income, parental educational level) and social conversion factors (employability policies, income and incentives policies). These two dimensions influence how a person can convert the characteristics of the commodity into a functioning (achievement). However, 
such accomplishment cannot occur without freedom (choice) and equality. Sen (1992) asserted that having the freedom and capability to do something imposes the duty to consider whether to do it or not, which involves individual responsibility. In the case of employment, as Bonvin and Galster (2010) stated, "employability is more than the ability to access work; it is about the real freedom to choose the job one has reason to value" (p. 72). Hence, in the context of this study, "capabilities" is related to the ability of the students to enroll in TVET, whereas "functioning" refers to students' actual enrolment. For example, Saudi Arabia has technical colleges for both women and men (capability); however, women find it difficult to enroll in such programs (functioning) due to such social influences as unequal gender roles and disparate facilities. From this perspective, Saudi students need more than opportunities to access the skills and abilities necessary for work, they also need valuable opportunities that contribute to human flourishing within the labor market.

\section{The increasing need for TVET education}

Global economic transformations fuelled by technological advances have increased the demand for skilled workers, and many rapidly expanding industries are currently experiencing serious shortages of trained labor to meet the needs of the global market. As a result, large numbers of expatriates have been employed to fill the gap between demand and supply in fields such as manufacturing, services, and information technology (Kizu et al. 2018; Mellahi 2000). However, according to Looney (2004), the imbalance between low economic growth and increasing population is one of the greatest challenges impeding developing economies. Closing the gap between the needs of the labor market and the output of the education system has become a priority for sustainable economic development (Bilboe 2011). Whenever an expansion in the labor market occurs and training is closely linked to available jobs, the financial returns from vocational education and training in less developed countries have been reported to be higher than the financial returns from general education (Aizenman et al. 2018; Igarashi and Acosta 2018; Looney 2004).

Rapid social, political, economic, technological, and educational transformation has contributed to changing perspectives on both the need for and the nature of vocational and technical education. In Saudi Arabia, according to statistics from the Technical and Vocational Training Corporation (2018), the percentage of students enrolling in technical college programs in 2017 increased by 17\% from the previous year for 2-year technical diploma programs, by $23 \%$ for international technical colleges (excellence colleges), and by $20 \%$ for trainees in specialized institutes operated in partnership with the private sector.

In a 2017 report, the World Bank argued that improving employment rates in the Gulf States depends on the ability of governments to increase the attractiveness of private sector jobs and citizens' willingness to be employed in the private sector. The Saudi Arabian government has taken up this challenge to develop its nation's human resources (Al-Rasheed 2002); however, the lack of preparedness of Saudi citizens to take up certain types of employment opportunities remains problematic. Vision 2030 has initiated reform policies to meet the expectations of a rapidly expanding young Saudi population by facilitating the transition into the labor market. From 2012 to 2017, the localized 
oil and gas sector grew from 40 to 75\% (Hvidt 2018). In 2018, the Kingdom launched major labor market reforms to stimulate growth in other industrial sectors by extending Saudi-only jobs to include the sale of watches, eyewear, medical equipment and devices, electrical and electronic appliances, auto parts, building materials, carpets, cars and motorcycles, home and office furniture, children's clothing and men's accessories, home kitchenware, and confectionery (Young 2018).

The Saudi Arabian government has supported the Technical and Vocational Training Corporation through increased funding and the implementation of initiatives to improve TVET and expand opportunities for women (Khan et al. 2017). The labor force participation rate among Saudi women has gradually increased from 14\% in 1990 to $22 \%$ in 2017 (Arabi 2018). Increasing enrolment rates of women in technical and vocational training and development has been a major goal of recent initiatives (Khan et al. 2017). Among the 15 million jobs that Saudi Arabia plans to create by 2030, women are expected to occupy 3.6 million of the 11 million positions reserved for nationals (Saudi Vision 2030 n.d.).

As discussed in more detail below, Saudi nationals, in general, have preferred to take up limited white-collar jobs, leaving gaps in the job market largely consisting of skilled and manual employment opportunities. Because of a preference for wanting to earn large amounts of money in white-collar jobs, many Saudi workers refuse to take jobs in other sectors of the economy, resulting in higher-than-expected levels of unemployment for such a prosperous country (Yamada 2018). Many students refrain from enrolling in technical and vocational training programs because they believe that jobs in this area offer fewer financial incentives than white-collar jobs. However, a substantial gap exists between student assumptions in this regard and the reality concerning employment opportunities and incentives following TVET. As a result of these factors, Saudi Arabia's private sector capability has plummeted because of poor skill-matching job creation policies that have not taken the demands and realities of the economy sufficiently into account (Mellahi 2000).

\section{Global socio-economic context of TVET}

Much of the vocational education literature has highlighted its positive effects on economic development. However, several studies have also examined the factors that negatively affect students' ambition to enroll in vocational education, which appears to be generally rooted in the lower social prestige associated with TVET. Student's willingness to engage in TVET has been found to be closely linked to prevailing social and economic attitudes (Alasmeri 2012). Olesel (2010) studied the TVET situation in Australia and found that young people from lower socio-economic backgrounds were more likely to pursue this route than those from wealthier backgrounds. An unwillingness to clearly articulate the value of vocational education compared to traditional education and promote an integrated view of education has led students to attribute decreased importance to vocational education. Chankseliani et al. (2016) reported that the divide between academic and vocational education remains strong in the United Kingdom, so that those who pursue vocational education are less positively perceived in society than university students. 
Studies on the situations in Ghana and Nigeria have focused on the low public perception of TVET programs in many African countries, where those who participate were viewed as having low intellectual ability and as generally comprising school dropouts or illiterates (Aryeetey et al. 2011). Essel et al. (2014) similarly reported that many Ghanaian parents discourage their children from pursuing TVET programs due to the limited academic opportunities and lack of societal prestige with which these programs are associated. They attributed the stigmatization of TVET in Ghana and other African countries to the centering of colonial education in the humanities and a postcolonial drive to increase the proportion of white-collar workers and intellectuals. Similarly, Kennedy (2011) found that Nigerian students did not pursue TVET as their first choice due to its reduced social status and prestige in their community, which was reinforced by family and peers. As he asserted, "vocational and technical education has remained a subordinate discipline in terms of societal recognition, adequate funding, and parental/ children's choice" (Kennedy 2011: 172).

Agrawal and Agrawal (2017) indicated that in many Asian countries, TVET is viewed as providing opportunities for poor families with lower social prestige. They studied vocational training in India and showed that despite greater returns from vocational education than from academic education, perceptions of TVET remain generally negative in Indian society. Ayub (2017) similarly cited the low social prestige of TVET in Pakistan and reported that parents had a statistically significant role in influencing students' decisions to enroll in such programs whereby less educated parents with lower income and occupation levels were more inclined to encourage their children to pursue TVET.

There is a dearth of studies on the socio-economic context of TVET in the Arab Gulf states. However, Bilboe (2011) examined the primary factors contributing to the low numbers of students attending technical and vocational institutions in Kuwait and found that $51 \%$ of the study participants had not chosen vocational education as their first option, and most saw vocational education as providing limited preparation for the labor market. Rather, attending university was considered to offer better prospects for achieving higher socio-economic status. These results suggest that being ill-informed concerning what vocational education can offer is likely to contribute to decreased student interest in enrollment. Alnaqbi's studies (2016) focused on the attitudes toward vocational education and training in the United Arab Emirates and found that lower sociodemographic groups had less confidence and stigmatized themselves as being at the bottom level of the social hierarchy. Participants' negative images of TVET were largely influenced by parental choice and a desire for higher job salaries.

\section{Socio-economic context of TVET in Saudi Arabia}

\section{The stigmatization of TVET}

Vocational education does not operate in a vacuum but can be conceptualized as part of an overall system that may be culturally deeply rooted and strongly affected by the environmental constraints of a given country or region (Mellahi 2000). Saudi Arabian vocational training values and interests are very different from those in some developed countries (Alasmeri 2012), as Saudi Arabia faces major obstacles that limit the functioning of a successful vocational training system. As in many other Arab 
countries, a significant stigma is still attached to TVET pathways (Sultana 2017). A large proportion of Saudi society, especially those living in tribes, refuses to engage in specific occupations that conflict with their beliefs and ideas (Mellahi 2000). According to Thompson (2018: 75), "the real issue is not competition, but rather that young Saudis have not been educated to accept new socio-economic realities." As Thompson (2018: 77) observed, "companies are begging young Saudi men to start doing manual work, but they refuse because it remains culturally unacceptable."

Employability and salary play a part in students' attitudes to joining TVET. Madhi and Barrientos (2003) conducted a study to identify the conditions affecting employment and career development in Saudi Arabia. They found that available employment and career opportunities were strongly differentiated according to nationality and gender. The significant differences in career opportunities, mobility, conditions of work, and pay between Saudi and non-Saudi employees appear to have consolidated negative social attitudes among the former toward technical and vocational training. According to Mellahi (2000), "the distortion between wages for administrative jobs and skill jobs affect individuals' incentives to invest in vocational skills."

The stigmatizing of TVET in Saudi Arabia is also linked to factors of social prestige, which overwhelmingly derive from parental choices. Alandas (2002) studied attitudes of freshmen in Saudi technical colleges and found that their fathers' preferences were the primary factor influencing students' pursuit of TVET. However, the results did not indicate any statistically significant differences linked to parental academic level and income.

\section{Gendered restrictions in the labor market}

Many women have taken advantage of the Saudi Arabian government's efforts to increase academic educational opportunities, and women now constitute almost 53\% of students enrolled in Saudi Arabian universities (Koyame-Marsh 2016). However, the participation of educated women in the labor force remains relatively low. In 2015, 68\% of unemployed Saudi women had Bachelor's degrees or higher, compared with only 21\% of unemployed men (Koyame-Marsh 2016). Women in Saudi Arabia have traditionally been restricted to specific domains such as home economics, education, and nursing (Alfarran et al. 2018). Mellahi (2000) identified "misunderstanding of Islamic teaching, culture, and social tradition" as key factors hindering women's participation in the labor force. For many years, families did not allow women to work in physically demanding jobs such as factory production lines, leaving women with rather limited employment options as corporate secretaries or employment in service and sales industries. This constraint reduced the willingness of women to enroll in vocational education programs.

Calvert and Al-Shetaiwi (2002) examined the mismatch between technical and vocational skills and jobs for women in Saudi Arabia. In that study, a survey was distributed to 220 private sector business managers in four large cities to determine what factors they believed were important in affecting women's decisions to choose TVET and work in the private sector. The results revealed that managers saw the main factors affecting women's decision to pursue TVET were related to how technical and vocational training is structured rather than women's preferences or societal pressures. 


\section{Methodology}

\section{Processes and instrument}

This study used a self-developed questionnaire to assess the influence of the economic and social transformations embodied in Vision 2030 in changing the attitudes of Saudi youth toward vocational and technical education. The design of the survey adopted some concepts from Sen's $(1992,1993,1999,2009)$ capability approach with a focus on economic, political, and social factors. According to Sen (1992), social arrangements and policies should concentrate on what people are able to do and be, on the quality of their life, and on eliminating barriers in their lives so that they have more freedom to live the kind of life that they have reason to value.

The items of the survey were built in three phases. First, the researcher reviewed the policies of Vision 2030 that relate to TVET, including employment, foreign investment, women's empowerment, motivations and incentives, parent and student awareness, community effect, and social media (Saudi Vision 2030 n.d.). Nieuwenhuis and Shapiro (2004) proposed that developing TVET policies under constant and persistent pressure to reform will expand participation and reduce its negative image and stigma.

The second phase focused on triangulating the policies of Vision 2030 with several studies in the literature that focused on socio-economic and political factors influencing TVET, as well as incorporating studies utilizing a capability approach (see, for example, Alandas 2002; Madhi and Barrientos 2003; Lambert and Vero 2013; McGrath 2012; Powell and McGrath 2014; Alnaqbi 2016; Sultana 2017). The third phase was conducted by discussing the preliminary survey with ten experts in the TVET field to refine the survey, and their comments were considered.

Statistical analyses and percentages were derived from the questionnaire responses. The questionnaire consisted of two parts. In part one, socio-demographic data related to gender, marital status, monthly family income, study program, and parents' educational levels were gathered. Part two comprised an economic scale and a socio-cultural scale. In combination, the scales consisted of 25 items, and responses were measured on continuous 5-point Likert-type scales, ranging from (1) strongly disagree to (5) strongly agree.

The first scale comprised 12 items to assess the participants' views of the economic effects of Vision 2030 and how these policies have contributed to reduce the stigma attached to TVET. The second scale comprised 13 items that focused on participants' perceptions of the socio-cultural effects of Vision 2030 and how these policies have influenced participation in TVET. Table 1 presents the items from the two scales.

\section{Population and sample}

There is a total of 161,091 Saudi students (female $=24,154$, male $=136,937$ ) studying at technical colleges in thirty different technical colleges across the country. The unified nature of the college admission system means that the composition of student bodies in different colleges does not vary significantly. In theory, the optimal course would have been to choose a cross-section of student from all thirty colleges, but this would have been far beyond the capabilities and resources of the researchers. Students from three technical colleges in Riyadh, Dammam, and Al-Ahsa were chosen 
Table 1 Survey questions: influence of economic and social transformations on TVET participation

Scale 1: Influence of economic transformations

1-The orientation of Vision 2030 in creating new job opportunities has increased my motivation for technical and vocational training.

2-The economic shifts have increased my awareness of the importance of technical and vocational training.

3-The new Labor Office laws increasing the incentives for technical and vocational jobs (e.g., setting a minimum wage) have motivated me to pursue technical and vocational training.

4-Providing financial incentives in the private sector to those who have experience and technical and professional skills has increased my desire to participate.

5-Increasing opportunities for free post-employment scholarships and grants has increased my desire to enroll.

6-The National Transition Plan (2020), which includes a wide range of technical and professional jobs, contributed to increasing my desire to join technical and vocational training.

7-The ease of getting hired after graduation from technical and vocational training has contributed to increasing my desire to enroll.

8-The government agreement to allow foreign investment within its territory has strengthened the role of the private sector and the demand for technical and vocational training.

9-I chose technical and vocational training because it helps build special projects with good financial returns.

10-Strengthening private-sector partnership with technical and vocational training for post-graduate employment increased my desire to enroll in technical and vocational education.

11-Increasing the number of projects in Saudi Arabia has increased the desire of young people for technical and vocational training.

12-The state's shifting emphasis on the diversity of sources of income rather than dependence on oil has increased my motivation to enroll in technical and vocational training.

Scale 2: Influence of social transformations

1-The involvement of Saudi youth in technical and professional careers has contributed to improving society's perception of technical and vocational education.

2-Social networking helped me to recognize the importance of technical and vocational training in achieving Vision 2030

3-Having friends working in technical and professional jobs has increased my motivation toward technical and vocational training.

4-Vision 2030 has helped to change the negative culture toward some technical and professional functions.

5-Vision 2030 has contributed to parents' awareness of the importance of technical and vocational training to motivate their children to enroll.

6- The role of social media in highlighting Saudi talents and inventors in the technical and professional fields contributed to changing my view of technical and vocational training.

7-The contribution of the state to raising the social status of graduates of technical and vocational colleges and their role in the advancement of society through the media (such as newspapers, television) has stimulated my desire for technical and vocational training.

8-The presence of private companies offering good financial incentives has strengthened the community's view of technical and vocational training.

9-Organizing social seminars and conferences on the importance of professional and technical work has improved negative attitudes toward technical and vocational education.

10-Secondary school teachers encourage students to enroll in technical and vocational training after graduation.

11-Supporting women's participation in technical and vocational work has changed the negative perceptions of technical and vocational training

12-The existence of special projects for some graduates of technical and vocational training has improved the negative attitude of society toward technical and vocational training.

13-The high employment rate of Saudi youth in private sectors has contributed to improving perceptions of technical and vocational training.

with a total 27,510 students, $(15,577,5670$, and 6263 , respectively). Theses colleges were chosen for three main reasons: they are major industrial and commercial cities, they attract students from all across the country, and the researchers had personal contacts in these schools to facilitate their research efforts. The study utilized a 
formula suggested by Kotrlik and Higgins (2001), and the estimated sample size was 384 students.

$$
\begin{aligned}
& n_{0}=\frac{(t)^{2} *(p)(q)}{(d)^{2}} \\
& n_{0}=\frac{(1.96)^{2} *(0.5)(0.5)}{(0.05)^{2}}=384
\end{aligned}
$$

where $n_{0}$ is the required sample size, $\mathrm{t}$ is the alpha level value of 0.05 in each tail $=1.96,(\mathrm{p})$ $(\mathrm{q})=$ estimate of variance $=0.25, \mathrm{~d}=$ acceptable margin of error $=0.05$.

To ensure that the required sample size is obtained, the research assistants were given 1250 paper-based questionnaires to be distributed randomly in the selected cities. Unexpectedly, 1016 questionnaires were returned from the assistants, and 1007 questionnaires were completed. Rusticus and Lovato (2014) asserts that increasing sample size enhances power and precision of the study. This sample included both students studying for a two-year diploma and those taking a bachelor's degree. Out of 27,510 students, the program of bachelor's degree includes 2667 students studying in the Riyadh, Dammam, and Al-hasa (1622, 950, and 95, respectively). The Students ranged in age from 18 to 24 , which is a comparatively small range.

All respondents gave written informed consent to participate in the study, and their anonymity was ensured. Ethical approval was granted by King Saud University, and the Saudi Arabia Technical and Vocational Training Corporation granted ethical approval and permission for data collection.

\section{Data collection and analysis}

The researcher and three assistants administrated the paper-based questionnaires by visiting the classrooms and laboratories to distribute the questionnaires. Although 1016 students completed the questionnaire, nine were discarded as incomplete, leaving a total of 1007 questionnaires. Following data collection, the responses were analyzed using SPSS version 24.0. Data entry was reviewed by a third party to ensure no mistakes were made or values omitted. Descriptive statistics were calculated for the independent variables and for all survey responses, and frequency analysis recorded means, standard deviations, and percentages for all responses. Mann-Whitney U tests were conducted to identify significant differences in responses based on gender or study program, and analysis of variance (ANOVA) was conducted to assess differences based on other socio-demographic variables. Skewness and kurtosis were assessed, and Tukey post hoc tests were performed for multiple comparisons.

The ANOVA model was: H0: $\mu 1=\mu 2=\mu 3=\mu 4=\mu 5=\mu 6 ; \quad$ H1: $\mu 1 \neq \mu 2 \neq \mu 3 \neq \mu 4 \neq \mu 5 \neq \mu 6$, where $\mu 1$ through $\mu 6$ represent each independent variable of gender, marital status, study program, family's income, father's level of education, and mother's level of education. The ANOVA equations include: $S S_{\text {total }}=\sum_{i=1}^{n}\left(\bar{X}_{i}-\bar{X}\right)^{2}$ : where SS total is the Sum of Squares (SS) based on the entire set in all the groups (independent variables). 
$S S_{\text {within }}=\sum_{i=1}^{k} \sum_{i=1}^{n}\left(\bar{X}_{i}-\bar{X}\right)^{2}$ : where SS within groups is the sum of squares within each individual group of gender, marital status, study program, family's income, father's level of education, and mother's level of education.

$S S_{\text {between }}=\sum_{i=1}^{k}\left(\bar{X}_{i}-\bar{X}\right)^{2}$ : where SS between groups is the sum of squares between these groups, calcluated as (gender_mean-total_mean) $2+$ (marital status_mean-total_mean) $2+$ study program _mean-total_mean) $2+$ (family's income_mean-total_mean $) 2+$ (father's education_mean-total_mean $) 2+$ mother's education_mean-total_mean)2.

For Mann-Whitney U tests, the equation is: $U_{1}=R_{1}-\frac{n_{1}\left(n_{1}+1\right)}{2}$ or $U_{2}=R_{2}-\frac{n_{s}\left(n_{2}+1\right)}{2}$ : $U_{1}=R_{1}$ - where $\mathrm{U} 1$ and $\mathrm{U} 2$ represent each respective group (gender or study program), $\mathrm{R}$ represents the sum of ranks in the sample, and $\mathrm{n}$ is the number of items in the sample.

Multiple regression analyses were conducted to investigate if socio-economic variables had a significant effect on responses to the total questionnaire as well as responses to individual scales. Regression coefficients were analyzed to identify which specific variables had the largest and most significant effects. The regression model was:

$\mathrm{Y}=\mathrm{b}_{0}+\mathrm{b}_{1} \mathrm{X}_{1}+\mathrm{b}_{2} \mathrm{X}_{2}+\ldots+\mathrm{b}_{6} \mathrm{X}_{6}$ : Where $\mathrm{Y}$ is the predicted value of the dependent variables (scores) and $\mathrm{X}_{1}$ through $\mathrm{X}_{6}$ represent each independent variable of gender, marital status, study program, family's monthly income, father's level of education, and mother's level of education; $b_{0}$ denotes the value of $Y$ when all of the independent variables are equal to zero (representing the value regardless of their socio-demographic status), and $b_{1}$ through $b_{6}$ are the estimated regression coefficients.

\section{Reliability and validity}

The survey was subjected to reliability testing before analyses were conducted. The stability or test-retest reliability of the survey instrument was obtained through pilot testing of 85 students, and the participants in this pilot-testing were excluded from the main study. Acceptable values in Cronbach's alpha are generally > 0.70 (Gliem and Gliem 2003). This analysis determined which items would be inappropriate within their currently assigned scale and guided re-assignment or deletion of the items, which resulted in a total of 12 questions for scale 1 and 13 questions for scale 2 . The alpha coefficient obtained for the revised scale was 0.976 , and the standardized Cronbach's alpha (score of each item with zero mean and unit variance) was nearly identical at 0.977. Reliability analyses for individual scales yielded Cronbach alpha values of 0.956 for scale 1 and 0.953 for scale 2 .

The factorability of the 25 final questionnaire items was analyzed in SPSS and several well-recognized criteria for the factorability of a correlation were used. First, each item correlated at least 0.5 with all other items on the questionnaire. Secondly, the KaiserMeyer-Olkin measure of sampling adequacy was 0.98 , well above the commonly recommended value of 0.6, and Bartlett's test of sphericity was significant $(x 2(300)=23,996.43$, $\mathrm{p}=0.000$ ). In addition, the communalities all equaled one. Initial eigenvalues extracted from principal components analysis identified two factors with values over one. The first factor was robust and measured 8.825, and the second robust factor measured 8.420. The two-factor solution, which explained $68.9 \%$ of the variance, was selected due to the leveling off of eigenvalues after two factors. A Varimax with Kaiser rotation resulted in two factors, as shown in Table 2. 
Table 2 Results of Varimax with Kaiser normalization

\begin{tabular}{|c|c|c|}
\hline & \multicolumn{2}{|l|}{ Factor } \\
\hline & 1 & 2 \\
\hline Scale 1-factor 1 & & 0.712 \\
\hline Scale 1-factor 2 & & 0.731 \\
\hline Scale 1-factor 3 & & 0.733 \\
\hline Scale 1-factor 4 & & 0.721 \\
\hline Scale 1-factor 5 & & 0.697 \\
\hline Scale 1-factor 6 & & 0.762 \\
\hline Scale 1-factor 7 & & 0.664 \\
\hline Scale 1-factor 8 & & 0.715 \\
\hline Scale 1-factor 9 & & 0.687 \\
\hline Scale 1-factor 10 & & 0.709 \\
\hline Scale 1-factor 11 & & 0.692 \\
\hline Scale 1-factor 12 & & 0.707 \\
\hline Scale 2-factor 1 & 0.586 & \\
\hline Scale 2-factor 2 & 0.717 & \\
\hline scale 2-factor 3 & 0.687 & \\
\hline Scale 2-factor 4 & 0.701 & \\
\hline Scale 2-factor 5 & 0.758 & \\
\hline Scale 2-factor 6 & 0.749 & \\
\hline Scale 2-factor 7 & 0.759 & \\
\hline Scale 2-factor 8 & 0.734 & \\
\hline Scale 2-factor 9 & 0.759 & \\
\hline Scale 2-factor 10 & 0.696 & \\
\hline Scale 2-factor 11 & 0.740 & \\
\hline Scale 2-factor 12 & 0.735 & \\
\hline Scale 2-factor 13 & 0.726 & \\
\hline Percentage of variance & 35.30 & 33.68 \\
\hline Eigenvalue & 8.825 & 8.420 \\
\hline Cronbach's alpha & 0.956 & 0.953 \\
\hline
\end{tabular}

Rotation converged in 3 iterations

Extraction method: Principal Component Analysis

\section{Results}

\section{Descriptive statistics}

Table 3 presents the sample's socio-demographic statistics. Of the 1007 participants, approximately $56 \%$ were male, and the majority were single individuals studying for two-year diplomas. Those whose families earned SR 10,000 (USD \$2667) or less per month constituted $72.1 \%$ of respondents, and most of the participants' fathers (60.8\%) and mothers (49.5\%) had attained at least a high school education level.

All respondents entered responses to each question. The results of a two-tailed Fisher's $\mathrm{F}$ test demonstrated that the mean values for both scales were similar (scale $1: \mathrm{M}=4.107, \mathrm{SD}=0.09$; scale $2 \mathrm{M}=4.097, \mathrm{SD}=0.086$ ), with no significant difference between the means of responses to scale items (Table 4). 
Table 3 Socio-demographic statistics

\begin{tabular}{llrr}
\hline Variable & Category & N & \% \\
\hline Gender: & Female & 442 & 43.89 \\
& Male & 565 & 56.10 \\
Marital status: & Divorced & 9 & 0.89 \\
& Married & 125 & 12.41 \\
& Single & 873 & 86.69 \\
Study program: & Two-year diploma & 927 & 92.06 \\
Family's monthly income: & Bachelor's degree & 80 & 7.94 \\
& Less than 5000 SR & 377 & 37.44 \\
& 5000-10000 SR & 34.86 \\
Father's level of education: & 10001-15000 SR & 137 & 13.61 \\
& More than 15000 SR & 142 & 14.10 \\
& Bachelor's degree & 217 & 21.55 \\
& Two-year diploma & 8.94 \\
& High school & 30 & 30.29 \\
Mother's level of education: & Less than high school & 305 & 39.23 \\
& Bachelor's & 395 & 19.27 \\
& Two-year diploma & 194 & 5.36 \\
& High school & 54 & 24.83 \\
& Less than high school & 250 & 50.55 \\
\hline
\end{tabular}

Table 4 Comparison of means for economic (scale 1) and social (scale 2) attributes

\begin{tabular}{llllllll}
\hline Variable & Observations & Min. & Max. & Mean & Std. deviation & F & p \\
\hline Scale 1 & 12 & 3.953 & 4.237 & 4.107 & 0.090 & 1.096 & 0.897 \\
Scale 2 & 13 & 3.877 & 4.232 & 4.097 & 0.086 & & \\
\hline
\end{tabular}

\section{Influence of socio-demographic variables}

Table 5 summarizes the mean values and standard deviations for the entire questionnaire as well as each subscale. Considering the maximum possible scores of 60 and 65 for scales 1 and 2, respectively, overall responses were positive. However, some responses to individual questions merit attention. For example, responses to question 11 on scale 2 revealed that almost $82 \%$ of respondents agreed or strongly agreed that increased support for the integration of women into TVET has helped to reduce negative perceptions of training in this field. Similarly, almost $78 \%$ of respondents agreed or strongly agreed that the Saudi Arabian government's use of media to improve perceptions of the social status of technical and vocational college graduates and their role in social advancement (scale 2, Q7) had motivated their interest in technical and vocational education.

When comparing total scores across both scales, mean scores for women and respondents studying for two-year diplomas were significantly higher than those for men and respondents studying for Bachelor's degrees. Mann-Whitney U tests showed significantly higher scores for females than for males on each scale (Scale 1: $\mathrm{U}=93,130, p=0.000, r=0.220$; Scale 2: $\mathrm{U}=91,978.5, p=0.000, r=0.229)$, and the differences between scores based on study course were also significant (Scale 1: $\mathrm{U}=22,341.0, p=0.000, r=0.188$; Scale 2: $\mathrm{U}=20,778.5, p=0.000, r=0.208$ ). 
Table 5 Mean questionnaire and subscale scores according to socio-demographic group

\begin{tabular}{|c|c|c|c|c|c|c|c|}
\hline Variable & Category & Total mean & SD & Scale 1 mean & SD & Scale 2 mean & SD \\
\hline \multirow[t]{2}{*}{ Gender } & Female & 107.28 & 16.53 & 51.74 & 7.96 & 56.14 & 8.67 \\
\hline & Male & 98.85 & 21.25 & 47.37 & 10.54 & 51.01 & 11.58 \\
\hline \multirow[t]{3}{*}{ Marital status } & Divorced & 97.44 & 16.52 & 46.11 & 8.77 & 50.56 & 6.44 \\
\hline & Married & 98.92 & 23.8 & 53.63 & 10.31 & 50.90 & 13.13 \\
\hline & Single & 103.12 & 19.10 & 49.61 & 9.47 & 53.63 & 10.31 \\
\hline \multirow{2}{*}{$\begin{array}{l}\text { Respondent's educa- } \\
\text { tion }\end{array}$} & Two-year diploma & 103.78 & 18.78 & 49.91 & 9.29 & 53.98 & 10.18 \\
\hline & Bachelor's degree & 88.24 & 24.76 & 42.12 & 11.79 & 44.91 & 12.99 \\
\hline \multirow{4}{*}{$\begin{array}{l}\text { Family monthly } \\
\text { income }\end{array}$} & Less than 5000 SR & 101.67 & 20.36 & 48.83 & 10.10 & 52.84 & 10.84 \\
\hline & 5000-10000 SR & 102.93 & 19.68 & 49.56 & 9.59 & 53.37 & 10.90 \\
\hline & $10001-15000$ SR & 102.79 & 18.88 & 49.46 & 9.18 & 53.33 & 10.37 \\
\hline & more than 15000 SR & 103.70 & 19.24 & 49.67 & 9.70 & 54.03 & 10.24 \\
\hline \multirow[t]{4}{*}{ Father's education } & Bachelor's degree & 102.24 & 20.98 & 49.06 & 10.30 & 53.66 & 10.93 \\
\hline & Two-year diploma & 105.14 & 20.01 & 50.29 & 9.74 & 54.36 & 10.81 \\
\hline & High school & 102.68 & 19.53 & 49.52 & 9.73 & 53.12 & 10.75 \\
\hline & $\begin{array}{l}\text { Less than high } \\
\text { school }\end{array}$ & 102.02 & 19.20 & 49.01 & 9.45 & 52.92 & 10.55 \\
\hline \multirow[t]{4}{*}{ Mother's education } & Bachelor's degree & 99.01 & 21.55 & 47.72 & 10.31 & 51.99 & 11.64 \\
\hline & Two-year diploma & 106.39 & 19.57 & 50.79 & 10.42 & 55.74 & 9.94 \\
\hline & High school & 103.07 & 19.72 & 49.39 & 9.99 & 53.36 & 10.46 \\
\hline & $\begin{array}{l}\text { Less than high } \\
\text { school }\end{array}$ & 103.24 & 18.95 & 49.67 & 9.26 & 53.43 & 10.51 \\
\hline
\end{tabular}

Although both groups expressed optimistic views, females' ratings were consistently higher than those of males. Pairwise comparisons between males and females showed that the largest differences concerned item 11 on scale 2 regarding the role of increased support for women's participation on improving societal perceptions of TVET ( $M=3.8$, $\mathrm{F}=4.4$ ) and item 7 on scale 1 regarding the ease of finding employment after TVET graduation $(\mathrm{M}=3.5, \mathrm{~F}=4.2)$, such that $69 \%$ of males agreed or strongly agreed regarding the former compared with $90 \%$ of females, and $63 \%$ of males agreed or strongly agreed with the latter compared with $83.9 \%$ of females.

Means comparisons for other groups did not indicate any significant between-group differences for either the whole test or for individual scales, with the exception of mother's level of education, for which ANOVA results indicated a significant effect on total scores $(F(3,1003)=3.04, p=0.028)$. As shown in Fig. 1, participants' whose mothers had a bachelor's degree reported lower mean values across both scales; however, Tukey multiple comparisons revealed no significant differences between groups. Because the Tukey post hoc is more conservative and attempts to control the overall alpha level, it was decided to conduct individual independent sample t-tests between those whose mothers had a bachelor's degree and those whose mothers had different education levels. The results showed significant differences in total scores for both scales between those whose mothers had a bachelor's degree and those whose mothers had less than a high school diploma $(t(701)=2.426, p=0.011)$, those whose mothers had high school diplomas $(t(442)=2.067, p=0.039)$, and those whose mothers had earned two-year diplomas $(t(246)=2.27, p=0.024)$. Although mean values exceeded 3.50 for all responses, pairwise comparisons confirmed that mean response values for participants whose mothers 


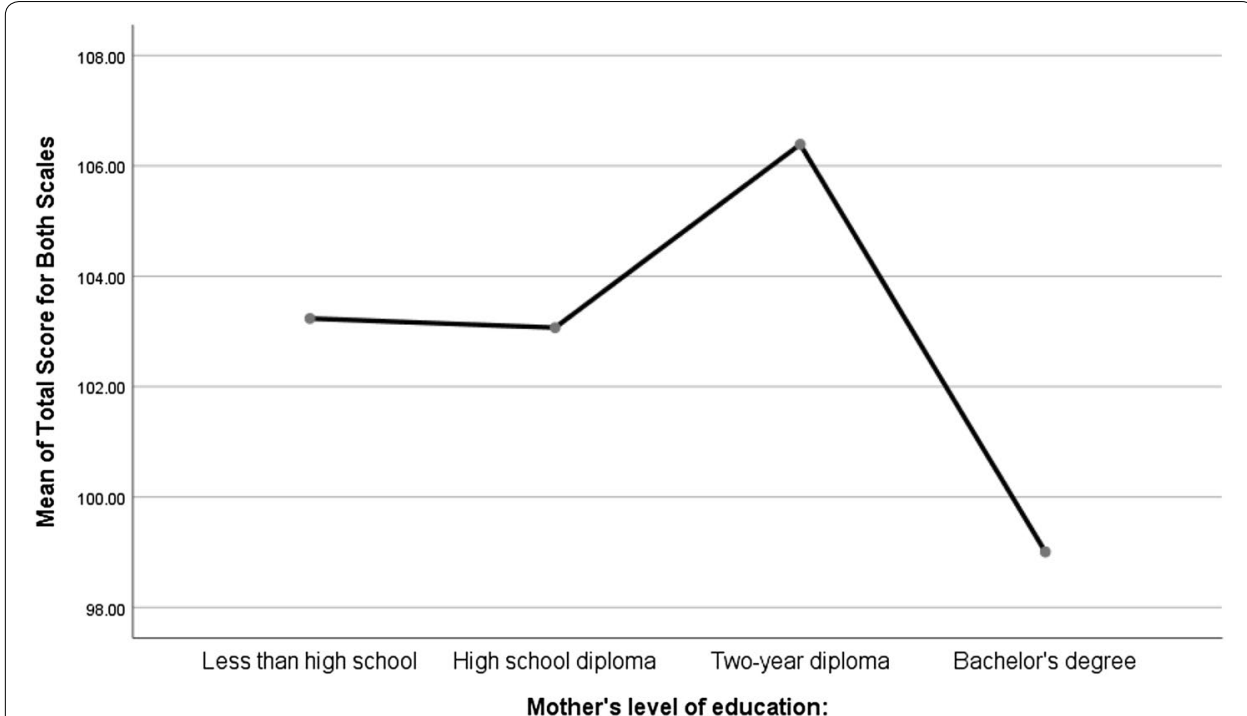

Fig. 1 Mean values for total questionnaire scores based on mother's level of education

had a bachelor's degree were consistently lower than those in other education categories across both scales, and this variable had a significant negative effect $(p<0.05)$ compared with those with mothers having a two-year diploma or a high school degree on several items on scale 1, including items concerning the positive effects of providing financial incentives in the private sector (Q4), the National Transition Plan (Q6), and the ease of gaining employment after graduation (Q7). In fact, such respondents' mean response for the last item was the lowest of all questionnaire items (3.52). On scale 2, the only items for which the effect of having a mother with a bachelor's degree was not significant were question 8 , concerning the effect of private companies offering good financial incentives, and question 12, concerning the existence of special projects for technical and vocational training graduates. Many of the scale 2 questions for which this variable had a significant negative effect $(p<0.05)$ on responses were related to societal perceptions of technical and vocational training. Indeed, the item that showed the greatest negative effect of having a mother with a bachelor's degree on both scales was question 11 regarding the effect that supporting women in TVET had on improving societal perceptions. In contrast, having a father with a two-year diploma had a positive and significant effect $(p<0.05)$ on one-third of the questions from scale 1 and $39 \%$ of the questions on scale 2 , including questions regarding economic shifts and new labor laws, and the diversifying economy in scale 1 . Notably, having a father with a two-year diploma also had a positive influence on responses to scale 2 questions regarding parents' increased awareness of the importance of technical and vocational training (Q5) and the role of increased support for women in reducing the stigma of TVET (Q11). Also notable was the significant negative effect $(\mathrm{p}<0.05)$ of being divorced on responses to scale 1 items, namely, motivation due to company incentives $(\mathrm{Q} 4)$ and young adult motivation due to an increased number of national projects (Q12).

Pairwise comparisons showed that the significance of family income varied across all items; however, the mean values of the responses of respondents whose families 
earned less than SR5,000 (USD \$1333) per month were consistently lower than those from higher-income families regardless of gender. Having a family monthly income of SR5,000 or less had a significant negative effect $(\mathrm{p}<0.05)$ on responses to half of the scale 1 items and $39 \%$ of the scale 2 items. Specifically, in terms of economic dimension (scale 1), low income had a significant negative effect on responses to whether there had been increased job opportunities due to Vision 2030 and the National Transition Plan (2020) (scale 1: Q1 and Q6). However, this group provided more positive responses regarding whether providing financial incentives $(\mathrm{Q} 4)$, an increased number and quality of national projects (Q11 and Q9, respectively), and economic diversification (Q12) had a positive effect on TVET participation. On scale 2 (social factors), low income had a significant negative effect on several items relating to the stigma attached to TVET, including items 4, 11, and 12. A family income of SR5000-10,000 had a significant negative effect $(\mathrm{p}<0.01)$ only on responses to items concerning the positive impacts of Vision 2030 on technical and professional functions (Q4, scale 2).

Tables 6, 7, 8 present the results of multiple regression analyses conducted to identify the effects of socio-economic status on questionnaire results. As shown in Table 6, the combined effect of all socio-economic variables was significant both for the total questionnaire responses $(\mathrm{F}(6,1000)=15.64, \mathrm{p}=0.000)$ and for individual scales. However, the low $\mathrm{r}$ squared values indicate that additional socio-economic variables may also contribute to predicting the questionnaire results.

When individual variables were considered, Table 7 shows that gender was the greatest predictor of overall questionnaire responses, followed by the respondents' study program levels; however, all variables except marital status and father's level of education had a significant effect on total questionnaire responses.

Table 8 shows a similar pattern with regard to the variables that were the greatest predictors of participants' responses to the individual scales as well as the variables that did not have any significant impact.

\section{Discussion and conclusions}

The survey results indicate that overall, the survey respondents were optimistic about the economic and social transformation in terms of their impact on Saudi students' attitudes toward TVET. However, women and respondents studying for two-year diplomas had a significantly more positive perception of the economic and socio-cultural effects of Vision 2030 in changing their attitude toward TVET than men and individuals with higher education levels. In contrast, those at the lowest income level $(<S R 5,000)$ had a relatively less positive outlook on the effects of the economic and social transformation than other income groups, and those whose mothers had the highest level of education (bachelor's degree) tended to be relatively less optimistic than those whose mothers were less educated, particularly regarding the socio-cultural effects of government initiatives concerning TVET participation.

The distribution of responses to questions 4,11 , and 12 in scale 2 indicated relatively less optimism regarding the potential of economic and social transformation for eliminating the social stigma attached to TVET and participation in it among lower income groups, men, and individuals whose mothers had received higher education. These results partly align with Sultana's (2017) and Thompson's (2018) observations 


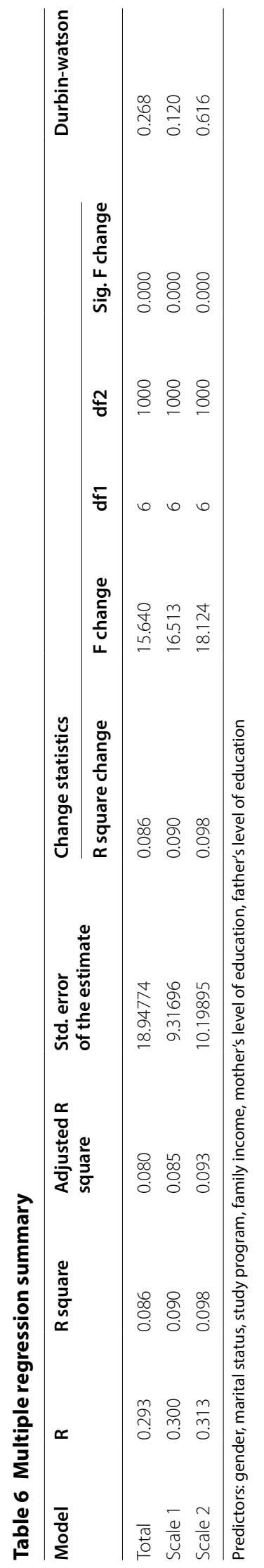


Table 7 Coefficients for socio-economic variables and total questionnaire responses

\begin{tabular}{|c|c|c|c|c|c|}
\hline & \multicolumn{2}{|c|}{ Unstandardized coefficients } & \multirow{2}{*}{$\begin{array}{l}\text { Standardized } \\
\text { coefficients } \\
\text { Beta }\end{array}$} & \multirow[t]{2}{*}{$t$} & \multirow[t]{2}{*}{ Sig. } \\
\hline & B & Std. error & & & \\
\hline Gender: & -6.989 & 1.251 & -0.176 & -5.587 & 0.000 \\
\hline Marital status: & -0.194 & 1.746 & -0.004 & -0.111 & 0.912 \\
\hline Study program: & -13.223 & 2.494 & -0.181 & -5.302 & 0.000 \\
\hline Family's monthly income: & 1.783 & 0.640 & 0.094 & 2.788 & 0.005 \\
\hline Father's level of education: & 0.363 & 0.585 & 0.021 & 0.620 & 0.535 \\
\hline Mother's level of education: & -1.638 & 0.568 & -0.095 & -2.884 & 0.004 \\
\hline
\end{tabular}

concerning continued negative perceptions of TVET in Arab societies, together with numerous other studies that highlight prejudice toward vocational education in both developing and developed countries (Agrawal and Agrawal 2017; Aryeetey et al. 2011; Chankseliani et al. 2016; Remington 2018).

Regarding lower income groups' negative perceptions of TVET, Olesel's (2010) and Ayub's (2017) studies disagree with this result, indicating that young people from lower socio-economic backgrounds were more likely than students from wealthier backgrounds to participate in vocational education and training. Therefore, the respondents from lower-income groups in this study may prefer careers with satisfactory wages to alleviate their poverty and change their social class, which hinder them not to choose TVET. Johannesen-Schmidt and Eagly (2002) examined the relationship between income and social classification and found that when income increased, social stereotypes increased strongly in positive agentic characteristics. Although Alnaqbi (2016) found that lower socio-demographic groups have less confidence and stigmatize themselves as being at the bottom level of the social hierarchy, thereby increasing the potential of their considering TVET, poor salary levels were an important factor in creating this negative self-image. From the point of view of "capabilities," when individuals focus more on employment with attractive incentives as a valuable opportunity, they may choose to enroll in TVET. As quoted earlier, Bonvin and Galster (2010) state that "employability is more than the ability to access work; it is about the real freedom to choose the job one has reason to value" (p. 72). The study by Madhi and Barrientos (2003) revealed that lower career opportunities and wages appear to have consolidated negative social attitudes among Saudis toward technical and vocational training.

In the case of parental educational level, the results showed that respondents whose mothers had the highest level of education (bachelor's degree) had a negative perception of TVET. Such students and their parents might be more ambivalent regarding the benefits of technical and vocational training, although it could represent an opportunity for those with lower family incomes and more limited choices. While Alandas's study (2002) indicates that there were no statistically significant differences concerning parental academic level and income for students in choosing TVET, it was shown that stigmatizing TVET was linked to the parental influence of students' decision. Similarly, both Alnaqbi (2016) and Ayub (2017) reached the same conclusion regarding the influence of parental choice on students' decisions, that as long as the 


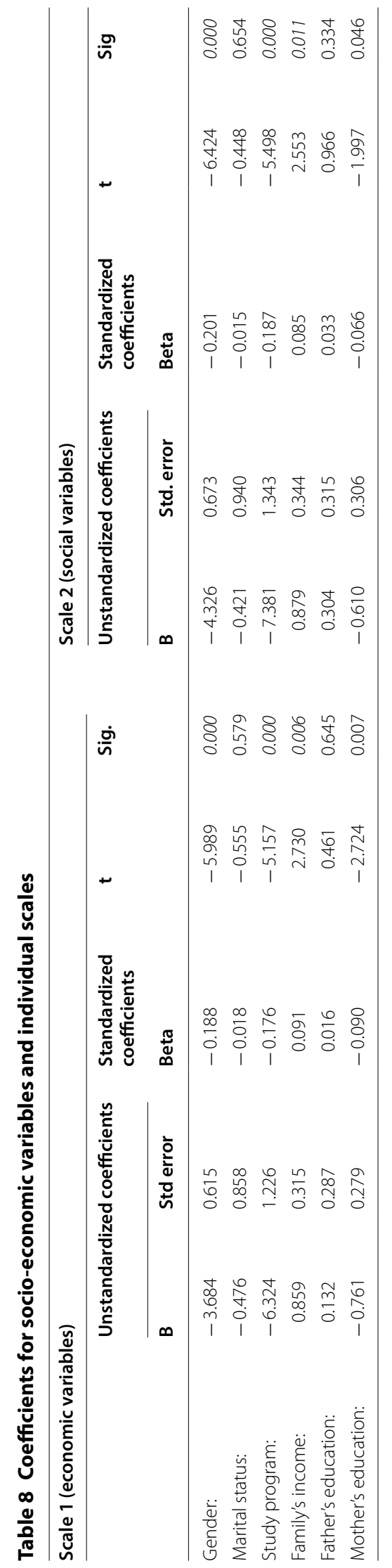


freedom to make decisions is absent, students will be far less likely able to pursue TVET. Sen (1992) states that a person's capability relies on the freedom to lead different sorts of lives, through being able to choose among different ways of living and different ways of 'being and doing. He also asserts that an individual's choice should not be linked to social or occupational stigmatization, demotion, or decrease in status (2009). From the perspective of capability, therefore, the more a prospective student takes account of their parents' educational level and feelings of social prestige (the conversion factors), the less likely they are to feel able to choose TVET.

However, due to the high average mean value for scale 2, it seems clear that many of those who actually participate in such programs feel hopeful that such negative views are changing, and based on the questionnaire responses, this is at least partly due to the government's initiatives. Bilboe (2011) found that being ill-informed concerning what vocational education can offer is likely to contribute to decreased student interest in enrolment. Increasing students' awareness concerning the importance of TVET through social media, teachers, and other factors may help to reduce the stigma toward TVET.

The results indicate particular optimism for the role that supporting women's participation in TVET can play in reducing the stigma attached to TVET. This contrasts with the findings of Calvert and Al-Shetawi (2002) mentioned earlier that the main factors affecting women's taking up of TVET was related to how technical and vocational training is structured rather than women's preferences or societal pressures. Our results also indicate a more optimistic view among students concerning the match between women's skills and technical and vocational jobs than was the case among the managers who participated in Calvert and Al-Shetawi's (2002) earlier study. In the period 1995-1996, women comprised only $5 \%$ of TVET students (Calvert and Al-Shetaiwi 2002) whereas, in this study, they comprised over $40 \%$ of participants. Moreover, although $83 \%$ of those surveyed by Calvert and Al-Shetaiwi (2002) claimed that there were limited technical and vocational jobs for women in the private sector, almost the same proportion of the current study's sample agreed or strongly agreed that the Saudi Arabian government's increased support for women's participation in TVET had helped to improve social perceptions of that field, thus suggesting that the Saudi Arabian government is making progress both in improving opportunities for women and reducing negative social perceptions of technical and vocational training and work. Therefore, supporting women through facilitating their needs would positively change their attitudes toward TVET. Sen (1992) sees capability, or opportunity for functionings, as the variable that should be equalized among individuals with taking their various different characteristics into consideration. If men and women hold equal primary goods, they are equally well-off, but the women might be at a disadvantage due to personal characteristics or gender roles.

Moreover, as noted, the mean values for both scales demonstrated high levels of positive views among all respondents regarding both the economic and the socio-cultural effects of Saudi Arabia's efforts to advance technical and vocational training.

This study can assist policy makers in updating legislation to promote relevant policies related to TVET. Specifically, it may contribute toward developing strategies to improve the societal view of vocational and technical training. Effective policies and strategies can concentrate on methods of teaching and training, improvement of educational infrastructure and environment, effective use of media and communications, and developing 
partnerships between companies in the private sector and vocational and technical training systems. Moreover, effective vocational guidance in secondary schools could be introduced to ensure that students are equipped with the skills, knowledge, experience, and attitudes required to make sound career decisions.

Regarding the first recommendation, as part of the National Reforms in Vocational Education and Training and Adult Learning, Poland's TVET system increased the number of practical training hours to improve teaching and training methods in 2016 (Doe 2019). To address the second recommendation, the Saudi government can look to examples such as Georgia, where measures to improve the vocational education learning environment have included developing modern infrastructure and providing access to advanced technologies and facilities (Ministry of Education, Science, Culture and Sport of Georgia 2013). Finally, the European Business Forum 2014 proposed measures to improve collaboration with the private sector (ICF 2014), noting that such partnerships should be informed by the demands of the labor market as well as students' interests.

This study has some limitations. The survey failed to ask students about which course they were studying. This information would have been useful in casting more light on the attitudes and responses of students studying different courses within the overall technical sector. This is a limitation which could be taken into account by future researchers. The study also focused on the attitudes of students currently enrolled in TVET programs and did not explore the views of young adults and others not participating in such training. In addition, this study did not obtain data on current employment rates for TVET program graduates, including women's employment rates. Future research should expand the sample to include young adults who are either enrolled in non-technical schools or not attending school, and longitudinal analyses would help to determine if students' views change after they have graduated and entered the employment market.

Abbreviation

TVET: Technical and vocational education and training

\section{Acknowledgements}

The author extends his appreciation to the Deanship of Scientific Research at King Saud University for funding this work, as well as providing the assistance in editing services through its cooperation with professional editors at Editage, a division of Cactus Communications.

Authors' contributions

The researcher committed to write and analyze the research, and then check it after receiving the comments from the editors and reviewers. The author read and approved the final manuscript.

\section{Funding}

This work was supported by the Deanship of Scientific Research at King Saud University under Grant number NFG-7-18-01-21.

Availability of data and materials

The datasets used and analysed during the current study are available from the corresponding author on reasonable request.

Competing interests

The author declare that he have no competing interests.

Received: 11 November 2019 Accepted: 7 April 2020

Published online: 11 April 2020

\section{Referencesz}

Agrawal T, Agrawal A (2017) Vocational education and training in India: a labour market perspective. J Voca Educ Train 69:246-265. https://doi.org/10.1080/13636820.2017.1303785 
Aizenman J, Jinjarak Y, Ngo N, Noy I (2018) Vocational education, manufacturing, and income distribution: international evidence and case studies. Open Econ Rev 29:641-664. https://doi.org/10.1007/s11079-017-9475-7

Al Omran A (2018) Record numbers of foreign workers leave Saudi Arabia, Financial Times. https://www.ft.com/content/ c710cf30-8441-11e8-a29d-73e3d454535d. Accessed 25 Sep 2019

Alandas S (2002) Attitudes of freshmen in Saudi technical colleges toward vocational-technical education. Dissertation, Ohio State University

Alasmeri M (2012) Acceptance of vocational industrial training between the culture of society and the future career: an applied study on the Saudi-Japanese institute in Jeddah. J of Kin Abdul Univ Econo Admin 105:1-113. https://doi. org/10.4197/Eco.26-2.2

Aldossari M, Bourne D (2016) Nepotism and turnover intentions amongst knowledge workers in Saudi Arabia. In: Jemielniak $\mathrm{D}$ (ed) The laws of the knowledge workplace: changing roles and the meaning of work in knowledge-intensive environments. Routledge, London, pp 25-34

Alfarran A, Pyke J, Stanton P (2018) Institutional barriers to women's employment in Saudi Arabia. Equ Dive Inclu Inter J 37:713-727. https://doi.org/10.1108/EDI-08-2017-0159

Alnaqbi S (2016) Attitudes towards vocational education and training in the context of United Arab Emirates: a proposed framework. Inter J Bus Manag 11:31-38. https://doi.org/10.5539/ijbm.v11n1p31

Al-Rasheed M (2002) A history of Saudi Arabia. Cambridge University Press, New York

Alshuwaikhat H, Mohammed I (2017) Sustainability matters in national development visions_evidence from Saudi Arabia's vision for 2030. Sustain 9:408. https://doi.org/10.3390/su9030408

Arabi K (2018) The impact of human capital on Saudi economic growth: emphasis on female human capital. Arch Busin Res 6:189-203. https://doi.org/10.14738/abr.612.5588

Aryeetey E, Doh D, Andoh P (2011) From prejudice to prestige: vocational education and training in Ghana. City and Guilds Centre for Skills Development; Council for Technical and Vocational Education and Training (COTVET-Ghana). https://unevoc.unesco.org/go.php?q=UNEVOC+Publications\&lang=en\&null=ft\&null=INS\&akt=id\&st=\&qs=5866. Accessed 29 Aug 2019

Ayub H (2017) Parental influence and attitude of students towards technical education and vocational training. Inter J Infor Educ Tech 7:534-538. https://doi.org/10.18178/ijiet.2017.7.7.925

Belcher J, DeForge B (2012) Social stigma and homelessness: the limits of social change. J Huma Behav Soci Envir 22:929-946. https://doi.org/10.1080/10911359.2012.707941

Bilboe W (2011) Vocational education and training in Kuwait: vocational education versus values and viewpoints. Intern J Train Res 9:256-260. https://doi.org/10.5172/ijtr.9.3.256

Bonvin J, Galster D (2010) Making them employable or capable? social integration policies at a crossroads. In: Otto H, Ziegler $\mathrm{H}$ (eds) Education, welfare and the capabilities approach: a European perspective. Barbara Budrich, Farmington Hills, pp 71-84

Bosbait M, Wilson R (2005) Education, school to work transitions and unemployment in Saudi Arabia. Mid East Stud 41:533-546. https://doi.org/10.1080/00263200500119258

Calvert J, Al-Shetaiwi A (2002) Exploring the mismatch between skills and jobs for women in Saudi Arabia in technical and vocational areas: the view of Saudi Arabian private sector business managers. Inter J Train Deve 6:112-124. https://doi.org/10.1111/1468-2419.00153

Chankseliani M, James Relly S, Laczik A (2016) Overcoming vocational prejudice: how can skills competitions improve the attractiveness of vocational education and training in the UK? Brit Educ Res J 42:582-599. https://doi.org/10.1002/ berj.3218

Dang A (2014) Amartya Sen's capability approach: a framework for well-being evaluation and policy analysis? Rev Soc Eco 72:460-484 https://doi.org/10.1080/00346764.2014.958903

Doe, J. (2019). National reforms in vocational education and training and adult learning. https://eacea.ec.europa.eu/ national-policies/eurydice/content/national-reforms-vocational-education-and-training-and-adult-learning-50_en. Accessed 21 Feb 2020

Essel O, Agyarkoh E, Sumaila S, Yankson P (2014) TVET stigmatization in developing countries: reality or fallacy? Euro J Train Dev Stud 1:27-42

Falk G (2010) Stigma: how we treat outsiders. Prometheus Books, New York

Faudot A (2019) Saudi Arabia and the rentier regime trap: a critical assessment of the plan Vision 2030. Resou Poli 62:94-101. https://doi.org/10.1016/j.resourpol.2019.03.009

General Authority of Statistics (2019a) Main indicators of the labor market. https://www.stats.gov.sa/sites/default/files/ labour_market_q1_2019_0.pdf. Accessed 29 Aug 2019

General Authority of Statistics (2019b) Population growth rate. https://www.stats.gov.sa/ar/indicators/1. Accessed 29 Aug 2019

Gliem R, Gliem J (2003) Calculating, interpreting, and reporting Cronbach's alpha reliability coefficient for Likert-type scales. Midwest research-to-practice conference in adult, continuing, and community education. Ohio State University, Columbus, pp 82-88

Gullekson M (1992) Stigma: families suffer too. In: Fink P, Tasman A (eds) Stigma and mental illness. American Psychiatric Press, Washington, pp 11-12

Hussain Z (2020) Nitaqat-Saudi Arabia's new labour policy: is it a rentier response to domestic discontent? In: Rajan S, Oommen G (eds) Asianization of migrant workers in the Gulf countries. Springer, Singapore, pp 151-175

Hvidt M (2018) The demographic time bomb: how the Arab Gulf countries could cope with growing number of youngsters entering the job market. Videncenter Om Det Moderne Mellemøsten?] https://findresearcher.sdu.dk:8443/ws/ files/144658674/Hvidt_Demographic_Timebomb_Dec 18.pdf. Accessed 5 Sep 2019

ICF (2014) European business forum on vocational training business \& vet-partners for growth and competitiveness. http://ec.europa.eu/education/events/20140923-business-vet_en. Accessed 21 Feb 2020

Igarashi T, Acosta P (2018) Who benefits from dual training systems? evidence from the Philippines. World Bank Policy Research Working Paper, (No. 8429). http://documents.worldbank.org/curated/en/576691525362185723/Whobenefits-from-dual-training-systems-evidence-from-the-Philippines. Accessed 15 Aug 2019 
Johannesen-Schmidt M, Eagly A (2002) Diminishing returns: the effects of income on the content of stereotypes of wage earners. Pers Soc Psych Bull 28:1538-1545. https://doi.org/10.1177/014616702237581

Kennedy O (2011) Philosophical and sociological overview of vocational technical education in Nigeria. Inter J Acad Res Bus Soc Scie 1:167-175

Khan F, Aradi W, Schwalje W, Buckner E, Fernandez-Carag M (2017) Women's participation in technical and vocational education and training in the Gulf States. Inter J Train Res 15:229-244. https://doi.org/10.1080/14480220.2017.13746 66

Khashan H (2017) Saudi Arabia's flawed "vision 2030". Mid Eas Quart 24(1):1-8

Kizu T, Kühn S, Viegelahn C (2018) Linking jobs in global supply chains to demand. Inter Labo Rev 158:213-244. https:// doi.org/10.1111/ilr.12142

Kotrlik J, Higgins C (2001) Organizational research: determining appropriate sample size in survey research appropriate sample size in survey research. Info tech learn perf J 19(1):43-50

Koyame-Marsh S (2016) The dichotomy between the Saudi women's education and economic participation. J Devel Area 54:431-441. https://doi.org/10.1353/jda.2017.0026

Lambert M, Vero J (2013) The capability to aspire for continuing training in France: the role of the environment shaped by corporate training policy. Inter J Manpow 34:305-325. https://doi.org/10.1108/JMM-05-2013-0091

Looney R (2004) Saudization and sound economic reforms: are the two compatible? Strat Insigh 3(2)

Madhi S, Barrientos A (2003) Saudisation and employment in Saudi Arabia. Care Devel Inter 8:70-77. https://doi. org/10.1108/13620430310465471

Markowitz F (1998) The effects of stigma on the psychological well-being and life satisfaction of persons with mental illness. J Heal Soc Behav 39:335-347. https://doi.org/10.2307/2676342

McGrath S (2012) Vocational education and training for development: a policy in need of a theory? Inter J Educ Devel 32:623-631. https://doi.org/10.1016/j.jjedudev.2011.12.001

Mellahi K (2000) Human resource development through vocational education in gulf cooperation countries: the case of Saudi Arabia. J Vocat Educ Train 52:329-344. https://doi.org/10.1080/13636820000200119

Mellahi K, Wood G (2001) Human resource management in Saudi Arabia. In: Budhwar P, Debrah Y (eds) Human resource management in developing countries. Routledge, London, pp 135-152

Ministry of Education (2018) Directory of specializations in higher education institutions. file:///C:/Users/ABDULAZIZ/ Downloads/Dalil-Al-Takhassosat.pdf. Accessed 20 Aug 2019

Ministry of Education, Science, Culture and Sport of Georgia (2013) Vocational education and training development strategy. https://mes.gov.ge/. Accessed 20 Aug 2019

Nieuwenhuis L, Shapiro H (2004) VET system change evaluated: a comparison of Dutch and Danish VET reform. In: Descy P, Tessaring M (eds) Evaluation of systems and programmes. Third report on vocational training research in Europe, Background report no 3, Luxemburg, 2004

Nussbaum M (2007) Capabilities as fundamental entitlements: sen and social justice. In: Kaufman A (ed) Capabilities equality- basic issues and problems. Routledge, New York, pp 54-80

Olesel J (2010) Vocational education and training (VET) and young people. Educ Train 52:415-426. https://doi. org/10.1108/00400911011058352

Powell L, McGrath S (2014) Exploring the value of the capability approach for vocational education and training evaluation: reflections from South Africa. In: Carbonnier G, Carton M, King K (eds) Education, learning, training: critical issues for development. Brill Nijhoff, Leiden, pp 126-148

Ramady M (2010) The Saudi Arabian economy: policies, achievements, and challenges. Springer, Dordrecht Heidelberg

Remington T (2018) Bureaucratic politics and labour policy in China. China Intern J 16(3):97-119

Robeyns I (2006) The capability approach in practice. J Polit Philo 14:351-376. https://doi.org/10.111 $1 / j .1467-9760.2006 .00263 . x$

Rusticus S, Lovato C (2014) Impact of sample size and variability on the power and type I error rates of equivalence tests: a simulation study. Pract Asses Res Eval 19(1):11. https://doi.org/10.7275/4s9m-4e81

Saudi Vision 2030 (n.d.) Kingdom of Saudi Arabia. vision2030.gov.sa/download/file/fid/417. Accessed 20 Sep 2019

Sen A (1992) Inequality reexamined. Oxford University Press, New York

Sen A (1993) Capability and well-being. In: Nussbaum M, Sen A (eds) The quality of life. Clarendon Press, Oxford, pp 30-54 Sen A (1999) Development as freedom. Knopf, New York

Sen A (2005) Human rights and capabilities. J Hum Devel 6:151-166. https://doi.org/10.1080/14649880500120491

Sen A (2009) The idea of justice. Allen Lane, London

Sultana R (2017) Career guidance and TVET: critical intersections in the Arab Mediterranean countries. Inter J Train Res 15:214-228. https://doi.org/10.1080/14480220.2017.1374667

Technical and Vocational Training Corporation (2018) Annual report. https://www.tvtc.gov.sa/Arabic/Documents/TVTC2 018Report.pdf. Accessed 23 Aug 2019

Thompson M (2018) The Saudi 'social contract' under strain: employment and housing. In: Lynch M, Cammett M, Fabbe K (eds) Social policy in the Middle East and North Africa. Belfer Center for Science and International Affairs, Harvard

World Bank (2019) Population growth. https://data.worldbank.org/indicator/SP.POP.GROW?locations=SA. Accessed 12 Aug 2019

Yamada M (2018) Can Saudi Arabia move beyond "production with rentier characteristics"? Human capital development in the transitional oil economy. Mid Eas J 72:587-609. https://doi.org/10.3751/72.4.13

Young K (2018) The difficult promise of economic reform in the Gulf. Baker III Institute for Public Policy of Rice University, Washington D.C, James A

\section{Publisher's Note}

Springer Nature remains neutral with regard to jurisdictional claims in published maps and institutional affiliations. 